\title{
Miasto, mit i Psyche \\ w imaginarium gier wideo. Symbolika miast i przedstawień miejskich - ujęcie psychoanalityczne ${ }^{1}$
}

\author{
Mirosław Piróg \\ iD https://orcid.org/0000-0001-8869-7604 \\ Linda Berezowska \\ (D) https://orcid.org/0000-0003-4873-6925
}

Artykuł podejmuje próbę przedstawienia symboliki miasta na gruncie psychoanalizy jako hermeneutyki kultury. Zestawiając ze sobą motywy mityczne z przykładami przedstawień miast w grach wideo, zarysowuje nierozerwalną ambiwalencję motywu miasta, podążającą za Freudowską strukturą osobowości i będącą wyrazem kompleksów składających się konstytucję ludzkiego psyche. Wykorzystanie gier wideo afirmuje uniwersalność programu hermeneutyki psychoanalitycznej, a także włącza tzw. nowe media do zakresu badawczych zainteresowań psychoanalizy. Praca jest syntezą seminariów pt. Mitologia Miasta. Podejście psychoanalityczne prowadzonych na Wydziale Nauk Społecznych Uniwersytetu Śląskiego w Katowicach w roku akademickim 2017/2018 przez dra hab. Mirosława Piróga wraz z Lindą Berezowską.

Słowa kluczowe: psychoanaliza, hermeneutyka, miasto, gry wideo, mitologia

MIROSŁAW PIRÓG, dr hab., Instytut Filozofii, Wydział Humanistyczny, Uniwersytet Śląski; adres do korespondencji: ul. Bankowa 11,40-007 Katowice; e-mail: miroslaw.pirog@us.edu.pl

LINDA BEREZOWSKA, lic., absolwentka studiów filozoficznych na UŚ; adres do korespondencji: ul. Bankowa 11, 40-007 Katowice; e-mail: linda.berezowska@gmail.com

${ }^{1}$ Praca powstała w ramach programu „Diamentowy Grant” finansowanego przez MNiSW. Numer rejestracyjny projektu: DI 20140054 44. Tytuł projektu: Miasta rozszerzone. Analiza wirtualnych miast $w$ świetle kulturowej socjologii - próba poszerzenia zakresu możliwości badawczych socjologii miasta. 


\section{Psychoanaliza jako hermeneutyka kultury}

Psychoanaliza została wypracowana jako jeden z dyskursów hermeneutycznych współczesności, który skupia się nie tylko na odczytywaniu tekstu, ale także na poszukiwaniu znaczeń innych form zachowania człowieka. Wypracowana pierwotnie przez Zygmunta Freuda w odniesieniu do wielu pozawerbalnych form komunikacji (marzenia senne, objawy neurotyczne, czynności pomyłkowe, gesty, mimika itd.) została z czasem wykorzystana do interpretacji całości wytworów kultury człowieka. W ten sposób psychoanaliza stała się narzędziem interpretacji nie tylko "psychopatologii życia codziennego", lecz także praktycznie wszystkich sfer życia człowieka współczesnego. Freud, jako jeden z „mistrzów podejrzeń” - obok Karola Marksa i Fryderyka Nietzschego - wypracował język, dzięki któremu hermeneutyka psychoanalityczna mogła dociekać ukrytych znaczeń wytworów kultury. Co więcej, ujęcie kultury w kategoriach hermeneutycznych z konieczności włącza do dyskursu człowieka jako takiego, rozszerzając tym samym do sfery twórczej i użytkowej zastosowanie metody analizy marzeń sennych².

Jednym $\mathrm{z}$ takich wytworów jest bez wątpienia miasto. W ciągu ostatnich tysięcy lat, od czasu rewolucji neolitycznej, życie człowieka coraz bardziej skupia się w przestrzeni miast. Obecnie już ponad połowa ludzkiej populacji żyje w miastach i nic nie wskazuje na to, by ten mega trend miał się odwrócić. Można powiedzieć, że człowiek współczesny to człowiek żyjący w mieście. Struktura miasta, jak każdego innego tworu kultury materialnej, jest zatem czymś, co może zostać poddane interpretacji psychoanalitycznej. Zastosowanie do tego narzędzi psychoanalitycznych jest dodatkowo uzasadnione tym, że psychoanaliza narodziła się w miejskiej atmosferze Wiednia końca XIX wieku i można ją traktować jako sposób samorozumienia specyficzny dla człowieka miejskiego. Miasto związane jest z psychoanalizą nierozerwalnie związane, zarówno historycznie jak i strukturalnie ${ }^{3}$.

Miasto stanowi kulturowy wytwór ludzkich uwarunkowań psychicznych, dlatego też poddane psychoanalitycznej hermeneutyce ujawnia psyche, która za nim stoi. O ile jednak fizyczne miasto jest budowanym przez pokolenia wyjątkowym monumentem psychicznych kompleksów, kompleksy te odgrywają tę samą rolę w akcie przedstawień miasta. Dlatego też, miasto w filmie, literaturze czy ma-

\footnotetext{
${ }^{2}$ Zofia Rosińska, Psychoanalityczne myślenie o sztuce (Warszawa: PWN, 1985), 195.

${ }^{3}$ Grzegorz Czemiel, „Psychoanaliza polis. Przyczynek do badań nad przestrzennymi praktykami politycznymi”, Śląskie Studia Polonistyczne 1, nr 3 (2013): 130.
} 
larstwie, hermeneutyka traktuje komplementarnie, odnajdując ciągłość w symbolice. Nie inaczej jest w przypadku gier wideo czy kultury cyfrowej jako takiej. Gry, jako stosunkowe nowe i wciąż rozwijające się medium, wydają się dla psychoanalizy szczególnie ciekawe, ponieważ angażują odbiorcę jako aktywnego uczestnika swoich treści. Dodatkowo, ze względu na niejednolitość środków wyrazu oraz częste techniczne kompromisy, gry oferują zaskakująco szerokie spektrum możliwych odniesień. Badanie świata przedstawionego w grze, ujawnia nam reprezentację redukcyjnego myślenie a o świecie jako takim, ale i nieświadome uwarunkowania, które determinują zarówno to jak taki świat zostanie skonstruowany, jak i to jak będzie on odbierany ${ }^{4}$. Z uwagi na tę zależność, punktów zaczepienia dla psychoanalizy $\mathrm{w}$ grach wideo jest potencjalnie więcej niż $\mathrm{w}$ jakimkolwiek poprzednim medium ${ }^{5}$.

Hermeneutyka psychoanalityczna jest narracją konstruowaną przez pacjenta psychoanalityka wokół wspomnień z wczesnego dzieciństwa. Perspektywę hermeneutyczną wprowadzili do psychoanalizy tacy filozofowie jak Jürgen Habermas czy Paul Ricoeur, jak również psychoanalitycy - Donald Spence i Roy Schafer ${ }^{6}$. W tym artykule wykorzystamy takie podejście do hermeneutyki psychoanalitycznej, traktując dostarczane przez nią pojęcia i schematy rozumienia jako narzędzia do interpretacji życia w mieście, tak jak jest ono odwzorowywane w wirtualnej rzeczywistości gier wideo.

Interesujące jest w tym kontekście podejście Schafera, dla którego rozumienie psychoanalityczne jest właśnie procesem narracyjnym. Jak każda inna opowieść, także narracja psychoanalityczna obejmuje jak najwięcej znanych psychoanalitykowi faktów, ale także ma dostarczać spójnego i przekonującego wyjaśnienia symptomów trapiących pacjenta. Według Schafera teoria psychoanalityczna jest autonomicznym czynnikiem, który doprowadza do ujęcia historii pacjenta jako swego rodzaju „mitu osobistego".

Struktura narracyjna zwana mitem zawsze wzbudzała ogromne zainteresowanie psychoanalityków. Już Freud we wczesnym dziele Totem i tabu(1912) uległ

${ }^{4}$ Eric Hayot, Edward Wesp, „Towards a Critical Aesthetic of Virtual-World Geographies”, Game Studies. The International Journal of Computer Game Research 9, $\mathrm{nr} 1$ (2009), http://gamestudies.org/0901/articles/hayot_wesp_space (dostęp 11.12.2017).

${ }^{5}$ Arlete dos Santos Petry, Luís Carlos Petry, „Possibilities of encounter between Psychoanalysis and videogames: thinking with Freud and Lacan", w: XI Simpósio Brasileiro de Jogos e Entretenimento Digital - SBGames 2012, Universidade de Brasília, Brasilia 2012, 9-18.

${ }^{6}$ Mitchell Stephen, Margaret Black, Freud i inni. Historia myśli psychoanalitycznej, tłum. Joanna Gilewicz (Kraków: Wydawnictwo Uniwersytetu Jagiellońskiego, 2017), 293. 
pokusie mitologicznego podejścia do kwestii wyjaśniania podstawowych mechanizmów psychologicznych. Carl Gustav Jung oraz Erich Fromm rozwijali to podejście w odrębny sposób, ale zwracając uwagę na zbiorową, mitologiczną strukturę narracji jednostki poddającej się psychoanalizie. Ten element narracyjny, fabularny, będzie przedmiotem naszego zainteresowania w dalszej części artykułu, $\mathrm{w}$ którym poddamy interpretacji rozmaite aspekty funkcjonowania miasta w kontekście fabuł konstruowanych przez twórców gier wideo.

Dobór gier wideo ma celowo charakter wyrywkowy i reprezentuje niewielki wycinek aplikowalnego materiału. W tym sensie, praca ta jest zaledwie przyczynkiem do głębszych studiów prezentowanych tu zagadnień. Celem nie było uzgodnienie zakresu pojęcia miasta $w$ jego niezliczonych wystąpieniach na łamach tak artystycznie bogatej, jak i formalnie niejednolitej sceny, przez którą to nowe medium się wyraża. Z jednej strony, chodzi o wyprowadzenie silnej paraleli takiego monolitu do konotacji mitycznych i archetypowych, tak doskonale już rozpoznanych w mediach starszych. Z drugiej zaś strony, ograniczenie się do wycinka gier podobnej proweniencji, gatunku i warsztatu technicznego nie oddałoby sprawiedliwości proponowanej w tej pracy tezie.

Kluczem wyboru materiału stała się więc bogata tekstualna warstwa charakterystyczna dla gatunków gier o rozbudowanej fabule, co jednocześnie pozwoliło zachować szerszą przekrojowość prezentowanych przykładów. Buduje to także pomost porównawczy pomiędzy dojrzalszymi mediami opartymi na tekście, oralnym i pisanym, a grami, będącymi - jakby nie patrzeć - zdominowanymi środkami wizualnymi oraz leżącą u ich bardziej analogowych źródeł interaktywnością.

Miasta, w podanych przykładach, nie stanowią zaledwie elementu aranżacji świata przedstawionego bądź wizualnego rekwizytu, lecz konstytuują fundamentalną przestrzeń narratologiczną, bez której wspomniane gry zostałyby pozbawione możliwości przekazania swojej treści. Są one również osią samej mechaniki rozgrywki ${ }^{7}$.

${ }^{7}$ Mnogość definicji gier wideo oraz klasyfikacji gatunkowej jest zagadnieniem ciekawym, które doczekało się wielu opracowań. Szerzej o definicji, podziale gatunkowym oraz warstwie narratologicznej zob. The Video Game Explosion: A History from PONG to Playstation and Beyond, red. Mark J.P. Wolf (Westport, Connecticut, London: Greenwood Press, 2008); Mark. J.P .Wolf, Building Imaginary Worlds: The Theory and History of Subcreation (New York and London: Routledge, 2012); Ernest Adams, Joris Dormans, Game Mechanics: Advanced Game Design (Berkley: New Riders, 2012); Maria B. Garda, Interaktywne fantasy. Gatunek w grach cyfrowych (Łódź: Wydawnictwo Uniwersytetu Łódzkiego, 2016). Wymienione pozycje są przykładowymi. 


\section{Archetypowe struktury i funkcje miasta w kontekście opozycji pierwiastków męskiego i żeńskiego}

$\mathrm{W}$ ujęciu psychologii analitycznej, miasto jest powiązane z pierwiastkiem żeńskim. Jego symbolika wywodzi się zatem z pierwotnej, archetypowej z sensie Junga, symboliki kobiecości, którą dokładnie opisał Erich Neumann w dziele Wielka Matka. Dowodzi on w nim, że fundamentalna symbolika kobiecości zawarta jest w równoważności znaczeń następujących domen symbolicznych; kobieta, ciało, naczynie, świat ${ }^{8}$. $Z$ formuły tej, obowiązującej jeszcze w świecie przedneolitycznym, wywodzi się symbolika chroniącej jaskini, prowadząca do dalszych domen symbolicznych: Chroniąca jaskinia jako część góry w kontekście rozwoju historycznego stanowi naturalną formę symboli kulturowych oznaczających zamknięta, strzeżoną przestrzeń - świątynia i temenos, chata i dom, wioska i miasto, ogrodzenie płot, mur, to, co zamknięte; bramy i drzwi stanowią tu łono macierzyńskiego naczynia"9. Jako zajmujące określoną przestrzeń, miasto funduje zatem swoje numinalne znaczenie na świętości pierwiastka żeńskiego. Miasto to zawsze mieszkanie bogini, która jest jego symboliczną personifikacją, jego „osobowością”. Można też pojmować miasto jako ciało bogini, na zasadzie symbolicznego powiązania między miastem, materią, przestrzenią i ciałem, które w symbolice noszą zawsze żeński charakter.

Przykładem takiej projekcji może być miasto Mournhold z gry The Elder's Scroll III: Morrowind. Poświęcone jest ono Almalexii, żywej bogini, która zamieszkując świątynię, otacza miasto swoją matczyną pieczą. Północny i południowy obszar miasta zajmuje odpowiednio świątynia bogini oraz plac z centralnie ulokowanym pomnikiem Almalexii, przebijającej włócznią boga Destrukcji, Rewolucji, Ambicji i kataklizmów. Życie miejskie zorganizowane jest jednak nie wokół kupców i przybyszów z sąsiednich prowincji, skupionych (głównie) na rozszerzaniu swych wpływów w domenie handlu, ale koncentruje się na kulcie bogini. Almalexia - znana także jako Matka Morrowind jest patronką uzdrowicieli oraz nauczycieli; nazywana Matką Uzdrowicielką, źródłem sympatii i współczucia, opiekunką ubogich i słabych. Stanowi ilustrację nie tylko łaskawości jako takiej, ale i mądrej przewodniczki po trudach codziennego życia mieszkańców.

\footnotetext{
${ }^{8}$ Erich Neumann, Wielka matka. Fenomenologia kobiecości. Kształtowanie nieświadomości, tłum. Robert Reszke (Warszawa: Wydawnictwo KR, 2008), 53.

${ }^{9}$ Tamże, 55.
} 


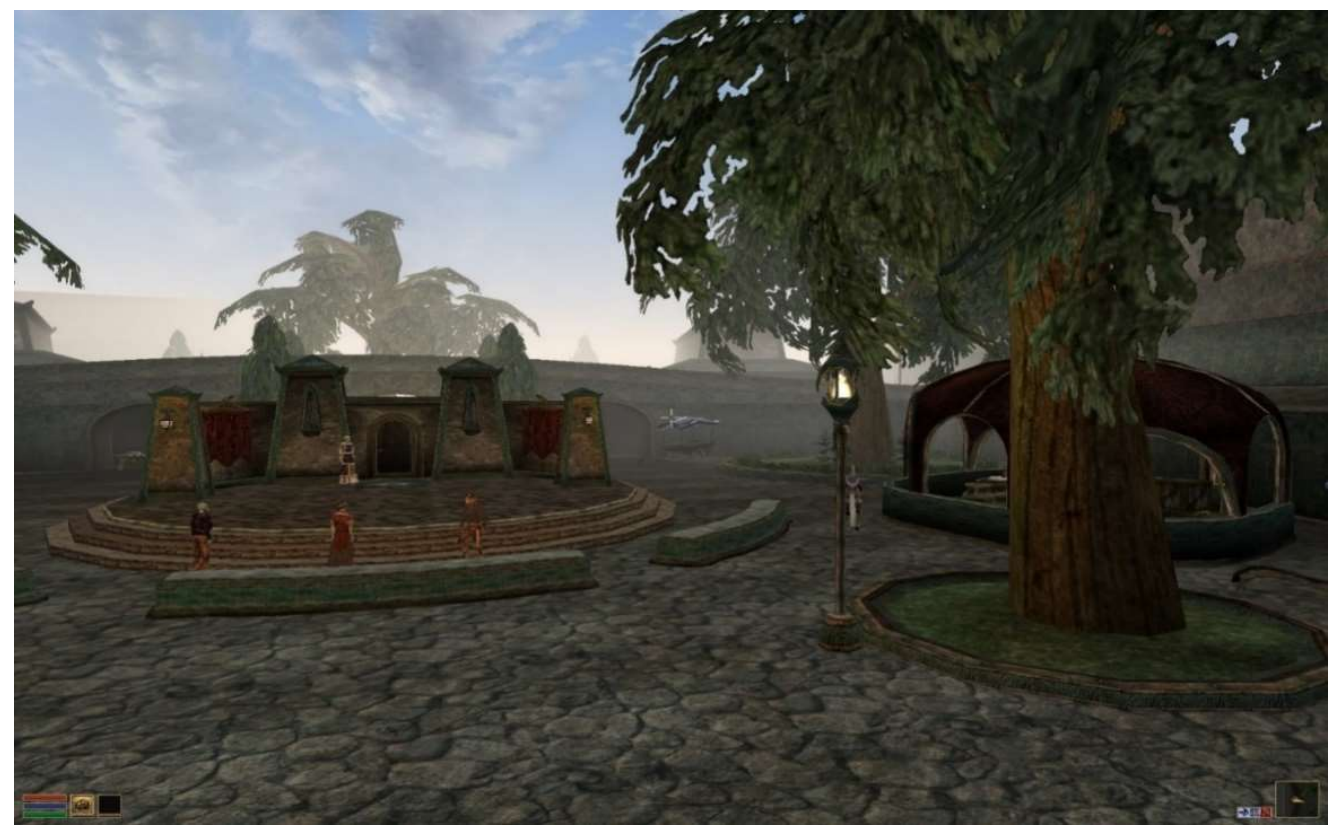

Mournhold, The Elder's Scrolls III: Morrowind

Przytoczone motywy mitologiczne są charakterystyczne dla pozytywnej, lunarnej symboliki miasta. Ma ona jednak także swój negatywny aspekt, związany $\mathrm{z}$ archetypem Strasznej Matki, kojarzonej ze śmiercią, pochłanianiem, ćwiartowaniem, niszczeniem, gniciem ${ }^{10}$. Ta ambiwalencja jest nieraz ujmowana jako przeciwstawienie dwóch stron miasta. Jak podaje Neumann:

Jako dobra matka jest ona panią Wschodniej bramy, Bramy narodzin; jako okrutna matka czuwa nad Bramą Zachodnią, Bramą Śmierci. Brama, drzwi, gardziel, przepaść i otchłań to symbole łona kobiecego, łona ziemi - jako miejsca numinalne wyznaczają one drogę wiodącą w mistyczne mroki świata podziemnego ${ }^{11}$.

W tej perspektywie, mieszkańcy miasta są z jednej strony dziećmi Wielkiej Matki, chronionymi przez nią macierzyńskimi murami, a z drugiej strony są embrionami, pożeranymi i wchłanianymi przez nieokiełznaną strukturę miasta. $\mathrm{Za}$ przykład może tuj posłużyć miasto Wykwit (ang. The Bloom) z gry wideo Torment: Tides of Numenera, które jawi się jako struktura unikatowa na tle innych

\footnotetext{
10 Tamże, 79.

11 Tamże, 176.
} 
miast w świecie przedstawionym gry. Położonym w Bezgraniczu (ang. The Beyond) mieście rządzi tzw. Memovira - tytuł nadawany władcom Wykwitu. Dotychczas było ich jedynie dwóch, a drugim, aktualnie panującym, jest okrutna kobieta o niezwykłej urodzie, która sprawuje pieczę nad przejściami do innych wymiarów. Bezgranicze to rozległa dzicz, pełna osobliwych zjawisk, przedziwnych, odseparowanych od siebie ludów, a także tyranów. Mimo swej nieobliczalnej natury, Wykwit nieustanie przyciąga zarówno kupców i poszukiwaczy. Wabi ich wizją fortuny zdobytej ze sprzedaży porozrzucanych po wymiarach lub ukrytych w krętych tunelach numeneró $w^{12}$ - bezcennego towaru w Dziewiątym Świecie (ang. The Ninth World) - a także schronieniem w mięsistych fałdach-komorach. Szanse na przetrwanie w tym mieście-drapieżczy mają jednak nieliczni. Głęboko w czeluściach Wykwitu znajduje się Gardziel (ang. The Gullet), organ miasta, który podtrzymuje siły witalne miejskich struktur. Zagubione artefakty, antyczne maszyny czy też resztki „intruzów” upolowanych przez bytujących tam łowców są budulcem miasta, które „wypluwa” wszelkie pozostałości, niestrawione resztki „pokarmowe” przez swe portale. Pozostali mieszkańcy miasta, ci niestrawieni, „płacą" miastu za ochronę paranoidalnymi zaburzeniami osobowości.

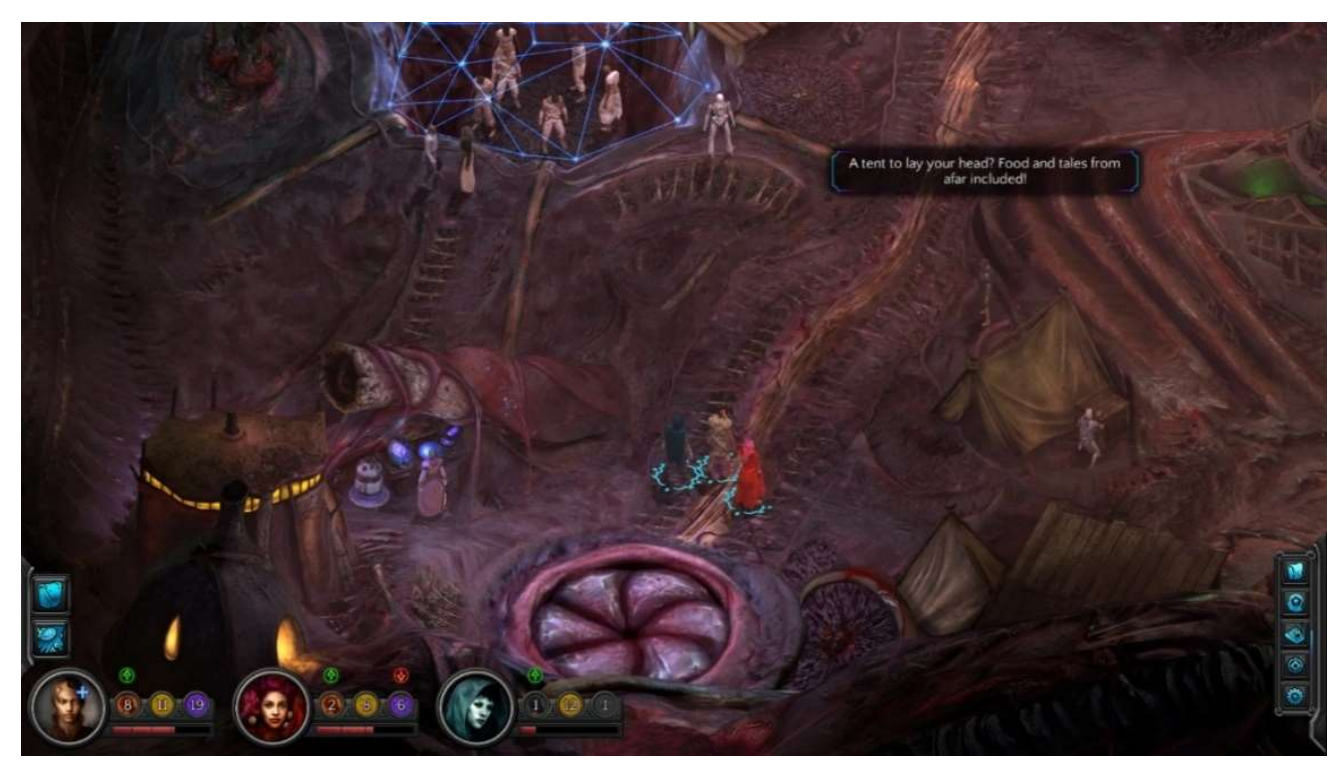

Wykwit, Torment: Tides of Numenera

${ }^{12}$ Terminem Numenera określa się w świecie przedstawionym wszelkie pozostałości po upadłych już cywilizacjach. Wyróżnić można kilka ich rodzajów: Osobliwości (ang. Oddities), Enigmaty (ang. $C y$ phers), Artefakty (ang. Artifacts), Znaleziska (ang. Discoveries). 
$\mathrm{Na}$ tą dialektykę związaną z pierwiastkiem żeńskim nakłada się symbolika zawiązana z opozycją pierwiastków żeńskiego i męskiego, która najpełniej przejawia się w znaczeniach domen symbolicznych porządku i władzy, które pojawiają się w hieratycznych miastach cywilizacji późnego neolitu, takich jak sumeryjska, egipska, minojska czy harrapańska. Nim jednak omówimy to zagadnienie, warto przytoczyć jeszcze znaczące słowa Ericha Fromma, które odnoszą się wprawdzie do współczesności, ale zachowują też ważność w odniesieniu do manifestacji technologicznych działań człowieka wszystkich epok:

\begin{abstract}
Nasza konsumpcyjna kultura kreuje nową wizję: jeśli pójdziemy dalej drogą postępu technologicznego, to w końcu osiągniemy punkt, w którym żadne życzenie nie pozostanie niespełnione, a spełnienie będzie natychmiastowe i nie wymagające jakiegokolwiek wysiłku. W wizji tej technika przybiera cechy Wielkiej Matki, już nie naturalnej, lecz technicznej, która niańczy swoje dzieci i koi je nieustanną kołysanką (w postaci radia i telewizji). Pod względem emocjonalnym człowiek na powrót staje się niemowlęciem, któremu poczucie bezpieczeństwa daje nadzieja, że pierś matki zawsze dostarczy obfitości mleka i że nigdy nie trzeba już będzie samodzielnie podejmować decyzji. Będą one bowiem leżały w gestii samego aparatu technologicznego, interpretowane i wcielane w życie przez technokratów nowych kapłanów rodzącej się religii matriarchalnej, której boginią jest Technika $^{13}$.
\end{abstract}

Fromm zwraca uwagę na oczywisty skądinąd fakt, że każde miasto jest przejawem technicznych umiejętności ludzi, zarówno w sensie zdolności do produkcji artefaktów, jak i zdolności do wytwarzania złożonej organizacji społecznej, bez której zbiorowy wysiłek owocujący zbudowaniem miasta byłby niemożliwy. Ta organizacja społeczna, skorelowana z rozwojem techniki, ma wedle Fromma charakter regresywny i infantylizujący.

Współcześnie, gdy już ponad połowa populacji planety żyje w miastach, słowa Fromma o „technicznej”, a nie naturalnej Wielkiej Matce brzmią złowieszczo. Nadmierne zagęszczenie populacji miast sprzyja spontanicznym i nieukierunkowanym manifestacjom dynamizmów ponadosobowych $\mathrm{w}$ ich obrębie. Jak pisze Jung: „Wszystko co przekracza w jakimś stopniu ludzki wymiar, wywołuje

${ }^{13}$ Erich Fromm, Miłość, płeć i matriarchat, tłum. Beata Radomska, Grzegorz Sowiński (Poznań: REBIS, 1997), 94. 
w takim samym stopniu nieludzkie siły w nieświadomości człowieka"14. W obliczu tych sił, adekwatna, indywidualna reakcja, wypływająca $\mathrm{z}$ określonych rozstrzygnięć etycznych, staje się prawie niemożliwa. To właśnie w mieście człowiek jest postawiony wobec potężniejszej od niego rzeczywistości, która nie jest już rzeczywistością sił czysto naturalnych, lecz jest w pewnej mierze jego własnym wytworem, efektem trwających tysiące lat przemian kultury ludzkiej. Miasto jest „materializacją" tego, co w człowieku ponadludzkie; nie znaczy to jednak - najlepsze.

\section{Miasto a władza - odwzorowanie boskiego i kosmicznego porządku (imago mundi)}

Miasto stanowi przestrzeń w specyficznej strukturze, wyznaczonej pierwotnie przez wierzenia religijne. Wedle badań archeologicznych, najstarsze miasta budowano wokół sanktuariów ${ }^{15}$. Miejsce nasycone sacrum było swego rodzaju jądrem krystalizacji, koncentrującym wokół siebie strukturę miejską. U podłoża powstania miast można zatem widzieć wierzenia, uznające że miasto posiada swój niebiański pierwowzór, jak na przykład niebiańska Jeruzalem ${ }^{16}$. Erygowane w ten sposób miasto, ustanowione przez centralny punkt, jakim jest świątynia, stanowi wzorcowy obraz kosmogonii. Jest miejscem, w którym panuje porządek przeciwstawiający się rozciągającemu poza obszarem miasta chaosowi. Dlatego założeniu miasta towarzyszyło symboliczne oddzielenie, zbudowanie progu czy też granicy, w postaci kamieni granicznych albo bruzdy - jak w micie o Remusie i Romulu$\operatorname{sie}^{17}$. Zabicie Remusa przez Romulusa było natomiast ofiarą założycielską.

Kosmiczny porządek odbijał się w konstrukcji miast, powstających na planie koła i kwadratu. Na przykład, starożytny Milet przypominał szachownicę, podobnie miasta Harrapa i Mohendżo Daro. Rzym (Roma quadrata) powstał przez zaoranie granicy i podzielenie powstałej w ten sposób wewnętrznej przestrzeni na

\footnotetext{
${ }^{14}$ Carl Gustav Jung, Civilization in transition (London: Routledge \& Kegan Paul, 1964), 226.

${ }^{15}$ Mircea Eliade, Historia wierzeń i idei religijnych, t. 1, tłum. Stanisław Tokarski (Warszawa: Instytut Wydawniczy PAX, 1988), 89.

${ }^{16}$ Mircea Eliade, Mit wiecznego powrotu, tłum. Krzysztof Kocjan (Warszawa: Wydawnictwo KR), 1998, 16-18.

${ }^{17}$ Zob. Mircea Eliade, Historia wierzeń i idei religijnych, t. 2, tłum. Stanisław Tokarski (Warszawa: Instytut Wydawniczy PAX, 1994), 76.
} 
cztery części za pomocą dwóch głównych ulic i szachownicowej sieci mniejszych $^{18}$. Ogólnie biorąc, chodziło w zbudowanie miasta na planie mandali, będącej archetypem porządku ${ }^{19}$. Również architektura miejska sama w sobie, niejednokrotnie wyraża poza funkcją użytkową immanentny porządek symboliczny stając się pomnikiem uświęconych idei. Sankt Petersburg, antyczny Rzym z czasów Hadriana, Nowa Huta czy niedoszły Berlin projektu Alberta Speera to całe miasta oparte na micie, czy to religijnym, politycznym czy historycznym ${ }^{20}$.

Wspomniany już Berlin można podziwiać w pełnej okazałości w grze Wolfenstein: The New Order, która oczami przebudzonego ze śpiączki komandosa o polskich korzeniach, B. J. Blazkowicza, ukazuje alternatywną wersję świata z roku 1960, w której naziści wygrali II wojnę światową, podbili Amerykę i zrealizowali wszystkie swe makabryczne plany. Blazkowicz, po ujściu z życiem ze szpitalnej czystki i otrząśnięciu się z szoku spowodowanego zastaną rzeczywistością, postanawia działać i organizować ruch oporu. Gdy dowiaduje się, że przyjaciele z jego jednostki wojskowej mogą wciąż przebywać obozie jenieckim, wyrusza w podróż do Berlina, który zastaje jako „miasto kamień” z dehumanizującą, monumentalną architekturą łączącą klasycyzm z brutalizmem.

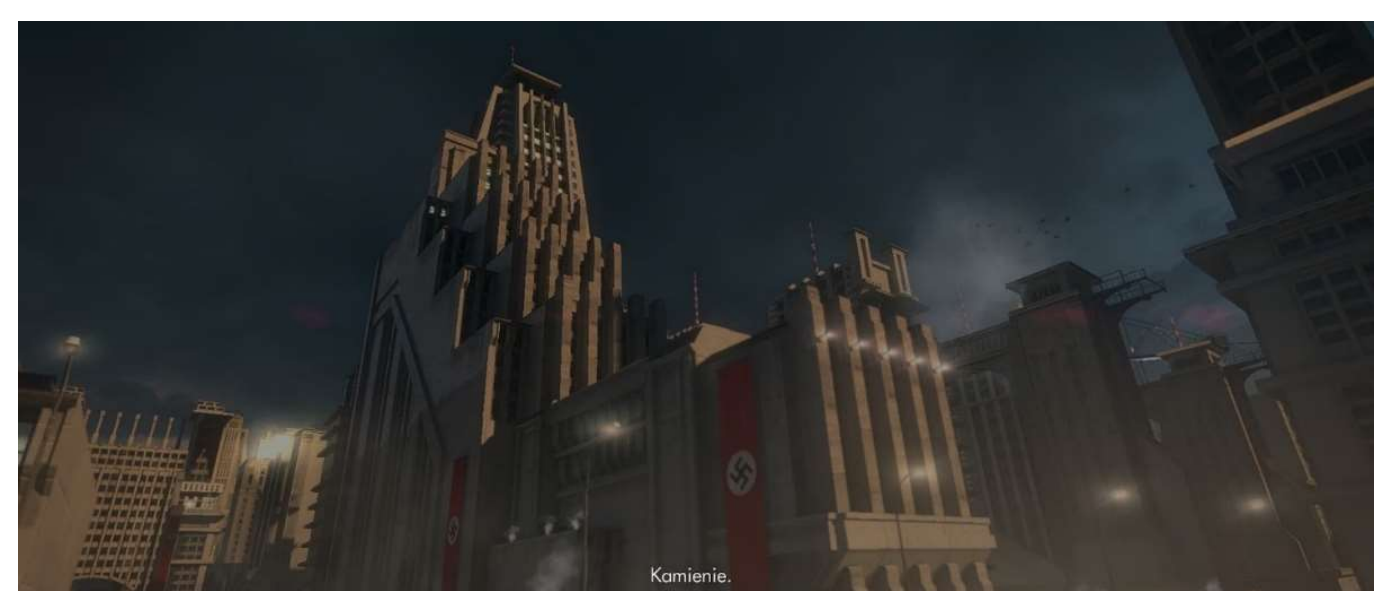

Berlin, Wolfenstein: The New Order

${ }^{18}$ Bolesław Szmidt, Lad przestrzeni (Warszawa: Państwowy Instytut Wydawniczy, 1981), 72.

${ }^{19}$ Zob. Carl Gustav Jung, Psychologia a alchemia, tłum. Robert Reszke (Warszawa: Wrota, 1999), 115-259; Giuseppe Tucci, Mandala, tłum. Ireneusz Kania (Kraków: Znak, 2002)

${ }^{20}$ Wade Graham, Miasta wyśnione. Siedem wizji urbanistycznych, które kształtują nasz świat, tłum. Anna Sak (Kraków: Wydawnictwo Karakter, 2016). 
Interesujący jest też świat w grze Elex. Akcja rozgrywa się na planecie Magalan, na której uderzenie komety zniszczyło cywilizację wraz z lwią częścią flory i fauny. Kometa ta sprawiła również, że na planecie pojawił się tytułowy Elex, który jest zasobem kopalnym o niezwykłej mocy. Pozostałości ludzkości, które przeżyły katastrofę, nauczyły się wykorzystywać ów materiał do różnych celów, a fundamentalna niezgoda co do poglądów zarówno na Elex, jak i na świat jako taki, doprowadza do rozłamu na wrogie sobie frakcje o różnych celach i stylach życia.



Goliet, Elex

Berserkowie postanowili kompletnie odrzucić użycie technologii i żyć w harmonii z naturą. Nauczyli się przetwarzać Elex w sposób, który użyźnia planetę i wierzą, że Elex powinien być wykorzystany do odrodzenia flory i fauny Magalan. Z kolei Klerycy, wręcz przeciwnie uważają, że jedynie inżynieria może uratować dogorywająca planetę. Elex służy im do rozwijania zaawansowanych technologii. $\mathrm{Na}$ inną frakcje składają się bandyci (ang. Outlaws), którzy za nic mają wyższe dobra, gromadząc Elex tylko po to, by się wzbogacić, a także by produkować silne narkotyki. Dodatkowo część Kleryków odłamała się od frakcji po odkryciu, że spożywanie Elexu daje człowiekowi supermoce. Stali się oni Albami (ang. Albs) uzależnionymi od Elexu i pozbawionymi zarówno emocji ,jak i pigmentu, ale zdeterminowanym do przywłaszczenia sobie całego dostępnego zasobu. 
Miasta, gdzie żyją te frakcje, zostały zbudowane i zorganizowane pod dyktando wiodących idei. Goliet, główny obóz Berserków, przypomina średniowieczny gród, a posiadanie czy użycie jakiejkolwiek technologii w mieście jest surowo zabronione; Hort, stolica Kleryków, to niezwykła świątynia poświęcona technologii, pełna robotów, broni laserowej i infrastruktury informatycznej.



Hort, Elex

Miasto jest konstrukcją, w obrębie której pojawia się czysto ludzki porządek świata, wzorowany wszelako na strukturach kosmicznych. Jest zbudowanym przez człowieka odzwierciedleniem kosmicznego i boskiego porządku ( $m e$ w Sumerze, maat w Egipcie, ryta $i$ dharma w Indiach). Jest więc wyrazem symbolicznej władzy człowieka nad siłami chaosu. Miasto jest także imago mundi, odbijającym w sobie kosmiczny porządek. Struktura miast jest odbiciem hieratycznej władzy króla, który jest ludzką reprezentacją ogólnego ładu kosmicznego. Król jest obrazem Słońca, królowa - Księżyca, a podstawowym motywem mitologii miasta jest hieros gamos ${ }^{21}$. Jest on centralnym rytuałem, który odzwierciedla podstawową jedność, konieczną do utrzymania porządku społecznego w mieście. Rytuał hieros gamos był spełniany na szczycie zigguratu, odzwierciedlającego archetyp Góry Kosmicznej, zalążka kosmogonii. Góra, centralne wzniesienie i ogień na ołtarzu

${ }^{21}$ Zob. Andrzej Szyjewski, Etnologia religii (Kraków: Nomos, 2001), 508. 
przynależą do symboliki męskiej, miasto, ołtarz, na którym plonie ogień przynależy do symboliki żeńskiej. W hieros gamos dochodzi do symbolicznego zjednoczenia przeciwieństw, co stanowi obraz narodzin, bogactwa i płodności. Jak twierdzi Andrzej Szyjewski: „Religioznawcy zwracają uwagę na szczególny związek władzy królewskiej ze Słońcem, stawiając hipotezy o związku rozwoju kultury miejskiej z solaryzacją władców, uważanych za 'synów Słońca'”22. W ten sposób pomiędzy mikrokosmosem jednostki a makrokosmosem natury budowano mezokosmos miejskiej struktury społecznej, dzięki któremu jednostka mogła uczestniczyć w szerszym, kosmicznym ładzie. Społeczności zbieraczo-łowieckie nie miały kłopotu z postrzeganiem ładu społecznego z powodu swej ograniczonej liczebności. Natomiast w mieście współżycie dziesiątków tysięcy jego mieszkańców staje się problemem, który musiał uzyskać sankcję religijną, manifestującą się zarówno w rytuałach, jak i w przestrzennej strukturze samego miasta.

\section{Pomiędzy świadomością a nieświadomością. Miasto jako Ego}

Już w strukturze Platońskiego polis odzwierciedlał się charakterystyczny dla tradycji indoeuropejskiej trójpodział struktury społecznej. Jak już wspomniano, miasto jest strukturą, której zadaniem jest zarówno ochrona mieszkańców zaprzed chaosem z zewnątrz, jak i porządkowanie chaosu wewnętrznego, wynikającego $\mathrm{z}$ nagromadzenia wielkiej liczby ludzi w jego obrębie. W tym sensie miasto jest opus contra naturam, jest sposobem organizowania ludzkiej psychiki poddanej wpływowi zbiorowości. Wtórnie owa organizacja odcisnęła się na pojmowaniu tejże, co możemy znaleźć u wielu myślicieli, od Platona do Freuda. U Freuda znajdujemy model strukturalny obejmujący kategorie id, ego i superego ${ }^{23}$. W znanej metaforze, w której porównuje on pracę ego do osuszania holenderskich polderów, widać ów cywilizujący aspekt pracy świadomości ${ }^{24}$. Ego jest „budowniczym miasta”, przeciwstawiającym się z jednej strony chaotyzującym wpływom id, a $z$ drugiej strony uwzględniającym surowe wymagania superego. Ego także

${ }^{22}$ Tamże, 509.

${ }^{23}$ Zob. Zygmunt Freud, Poza zasadą przyjemności, tłum. Jerzy Prokopiuk (Warszawa: PWN, 1975); Peter Kutter, Współczesna psychoanaliza, tłum. Aleksandra Ubertowska (Gdańsk: Gdańskie Wydawnictwo Psychologiczne, 1998), 74-76.

${ }^{24}$ Zygmunt Freud, Wykłady ze wstępu do psychoanalizy. Nowy cykl, tłum. Robert Reszke (Warszawa: Wydawnictwo KR, 2009), 62. 
„zamieszkuje miasto”, jego konkretyzacją jest mieszkaniec, który porusza się w strukturze miejskiej, wystawiony na rozmaitego rodzaju oddziaływania.

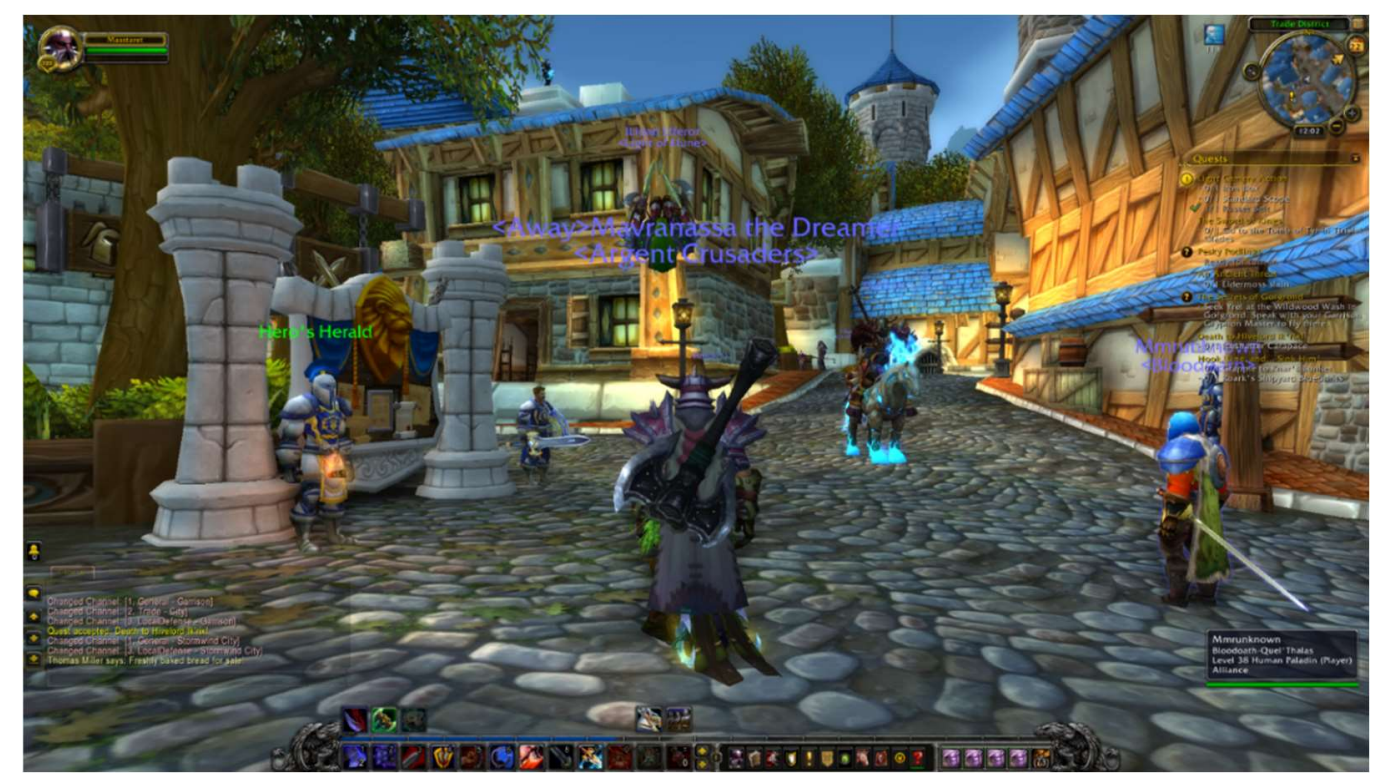

Stormwind, World of Warcraft

Interesujący jest sposób użycia miasta w wielu grach typu Role Playing Games (RPG). Począwszy od 1989 roku, gdy japońska gra Dragon Quest wzięła szturmem zachodnie rynki ${ }^{25}$, gry RPG w przeważającej mierze produkowało się powielając jej konwencje i rozwiązania mechaniczne; i chociaż dziś już rzadko występują w pierwotnej formie, wciąż można spotkać ich pokłosie. Jednym z takich rozwiązań były tzw. spotkania losowe (ang. random encounters) polegające na tym, że gracz przemieszczając się po świecie, co kilka minut był losowo atakowany przez miejscową faunę. Oznaczało to, że każda droga do celu nacechowana była ryzykiem śmierci bohatera lub drużyny, a także drenażem zasobów, takich jak mikstury uzdrawiające czy energia magiczna potrzebna do wykonywania ataków. Aby te zasoby uzupełniać, a także by wyleczyć postacie, gracz musiał dotrzeć do najbliższego miasta, które nierzadko było jedynym miejscem w całej grze, po którym można było się poruszać bezpiecznie. W nowoczesnych grach RPG również

${ }^{25}$ Chris Kohler, Power Up: How Japanese Video Games Gave the World an Extra Life (New York: Dover Publications, 2016), 210. 
zarysowuje się podział na niebezpieczną dzicz i bezpieczną przystań miejską. W World of Warcraft, gdzie gracz wybiera jedną ze stron konfliktu, do której dołącza, nawet w miastach należących do wroga, zamieszkanych przez rasy i frakcje, które poza miastem obrałyby nas za cel ataku, znajdujemy bezpieczną przystań.

Fundamentalny z punktu widzenia psychoanalizy podział psychiki na część świadomą i nieświadomą odzwierciedla podstawowe doświadczenie człowieka - podział cyklu dobowego na dzień i noc. W ujęciu psychoanalitycznym, każda struktura ma zatem dwa opozycyjne względem siebie aspekty: dobry i zły, jasny i ciemny. Także miasto ma owe dwa aspekty, „miasto dzienne” i „miasto nocne”, wyraźnie przejawiające się na przykład w opowieściach typu urban fantasy. Zacytujmy tu opisową definicję tych opowieści, którą podaje Andrzej Sapkowski:

Mianem urban fantasy określamy utwory utrzymane w poetyce pikarejsko-wielkomiejskich ballad Schelmenromanów, West Side Story, lub punk-rocka, w którym magia i fantazja wkraczają do betonowo-asfaltowej dżungli naszych miast. Ulicą Nowego Jorku przebiega biały koń, ratując bohatera z rąk młodzieżowego gangu i niosąc go w niesamowitą przygodę (Mark Helpirn, Winter's Tale). Elfy, inne magiczne istoty i demony grają w zespołach rockowych, jeżdżą metrem, a nocą szwendają się od McDonald's do Central Park. W tymże Central Parku, jakby nie mieli gdzie, dobrzy źli mieszkańcy Faerie urządzają sobie bitwę, istny Armagedon (Emma Bull, War for the Oaks) ${ }^{26}$.

Podobne traktowanie materii miasta jest obecne $\mathrm{w}$ grach, gdzie również w przestrzeniach wydawałoby się oswojonych, przenikniętych codziennością, nagle pojawiają się elementy i postacie ze sfery onirycznej, manifestacje nieświadomości.

Gdy trawiony twórczą niemocą pisarz Alan Wake, bohater gry o tym samym tytule, dociera do sennego miasteczka Bright Falls, ma nadzieję na zasłużony wypoczynek i nawrót chęci do pisania. Tydzień później budzi się z częściową amnezją, nie wiedząc gdzie podziała się jego żona, a na domiar złego po całym miasteczku i okolicznych lasach porozrzucane leżą strony maszynopisu jego najnowszej powieści, której tworzenia autor nie pamięta. Bright falls to normalna mie-

${ }^{26}$ Andrzej Sapkowski, Rękopis znaleziony w smoczej jamie. Kompendium wiedzy o literaturze fantasy (Warszawa: Wydawnictwo Supernowa, 2001), 46. 
ścina za dnia, ale po zmroku zmienia się w teatr grozy i absurdu, z którego bohatera ratują tylko rozpraszające mrok światło latarki i odwlekający sen termos z kawą.

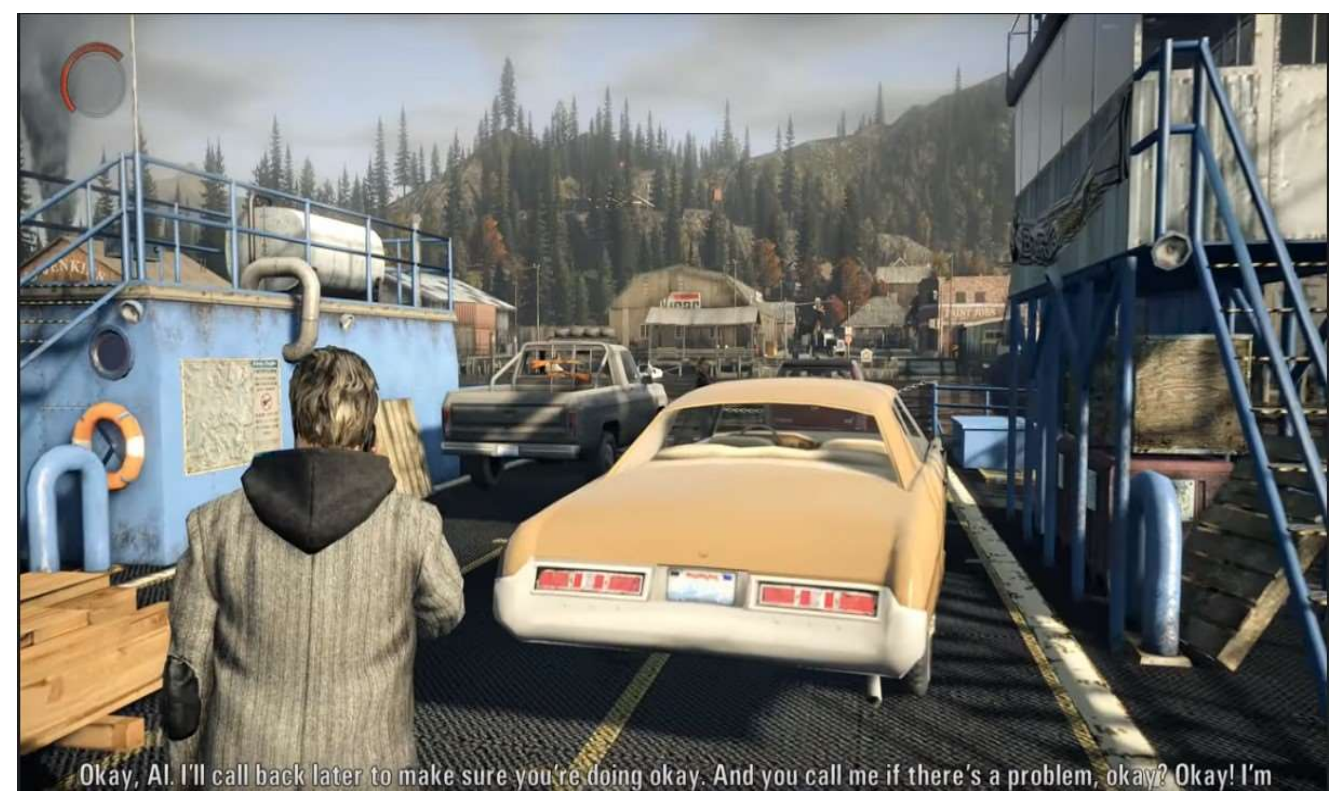

Bright Falls, Alan Wake

\section{Miasta Nocne i Miasta Dzienne}

„Miasto dzienne” $i$ „miasto nocne” przenikają się; podobnie jest z ludzką psychiką, gdzie nie można postawić jednoznacznej granicy między tym, co świadome, a tym co nieświadome. Miasto staje się w ten sposób miejscem realizacji mitu, w którym bohater (ego) dokonuje swej heroicznej podroży inicjacyjnej, choćby był to mit zdesakralizowany, jak w przygody Stefana Dedalusa w powieści Ulisses Jamesa Joyce'a ${ }^{27}$.

Specyfikę „miasta nocnego” można ująć przy pomocy Jungowskiej koncepcji cienia. Obejmuje on wszelkie nieświadome aspekty człowieka, jest obrazem archetypowym niższego, prymitywnego człowieka w nas, ale zarazem jest „pierwotną

${ }^{27} \mathrm{Na}$ temat podróży bohatera zob. Joseph Campbell, Bohater o tysiącu twarzy, tłum. Andrzej Jankowski (Kraków: NOMOS, 2013). 
predyspozycją naszej natury, którą odrzucamy ze względów moralnych"28. W mitologii pojawia się jako diabeł (Mefistofeles), faun, Loki itp., symbolizując irracjonalną stronę życia, wypieraną przez dążącą do czysto racjonalnych zachowań świadomość. Jak pisze Jung:

Cień jest jednak z reguły tylko tym, co niskie, prymitywne, nieprzystosowane i przykre, nie zaś absolutnie złe. Obejmuje on także właściwości naiwne i prymitywne, które w pewien sposób ożywiają i upiększają egzystencję ludzką, ale są obrazą dla zasad wpojonych człowiekowi. Warstwa wykształcona, kwiat naszej współczesnej cywilizacji, oderwała się od swych korzeni i bliska jest utracenia wszelkich związków z ziemią ${ }^{29}$.

Owa warstwa wykształcona to bez wątpienia mieszkańcy miast, licznie odwiedzający gabinety psychoanalityków, próbując $\mathrm{w}$ ich ramach zintegrować swoją ciemną stronę osobowości. W „mieście nocnym” cień przejawia się wszelako na sposoby, które nie jest łatwo ująć w jakiekolwiek ramy, jest źródłem istnej menażerii fantazmatów, obrazów i postaci zaludniających miasto nocą.

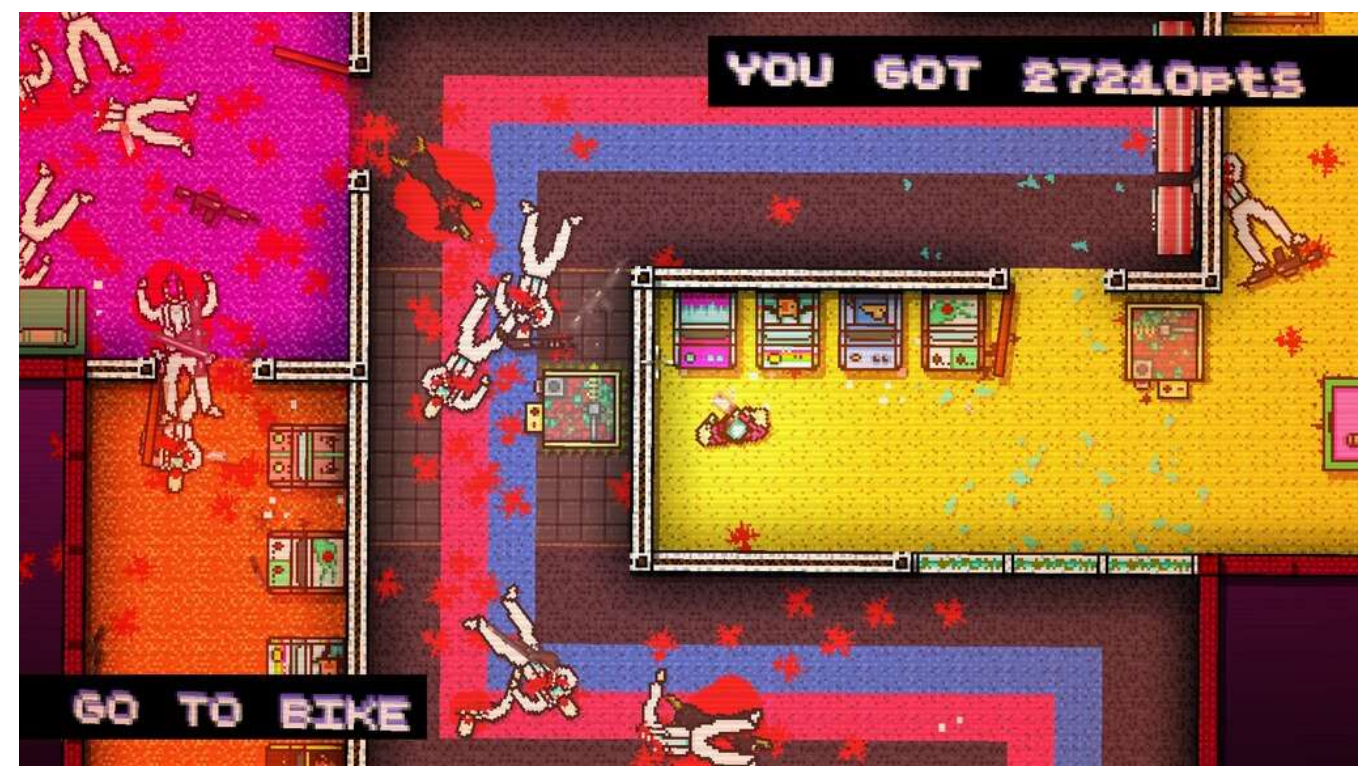

Miami, Hotline Miami

${ }^{28}$ Jolande Jacobi, Psychologia C.G. Junga. Wprowadzenie do całości dzieła, tłum. Stanisław Łypacewicz (Warszawa: Wydawnictwo Wodnika, 1993), 152.

${ }^{29}$ Carl Gustav Jung, Psychologia a religia Zachodu $i$ Wschodu, tłum. Robert Reszke (Warszawa: KR, 2005), 87-88. 
Za ilustrację posłużyć może gra Hotline Miami, zabierająca nas w neonowe realia lat 80, gdzie grana przez nas postać każdej nocy budzona jest telefonem przez jakichś żartownisiów nakazujących jej stawić się w to czy inne miejsce pod różnymi błahymi pretekstami. Nasz bohater niczym w transie wsiada do samochodu i wyrusza pod wskazany adres. Przed wejściem do środka wybiera ze swej kolekcji zwierzęcą maskę, która, po założeniu, łączy go z charakterystycznym dla danego zwierzęcia atawizmem. Po przekroczeniu progu staje się bezlitosnym, brutalnym mordercą, który dokonuje rzezi całego lokalu w akompaniamencie psychodelicznego rocka i muzyki transowej. Nie wiemy, czym kierowana postać zajmuje się w ciągu dnia; przejmujemy nad nią kontrolę dopiero w nocy, a każda noc odmalowuje ten sam schemat w coraz bardziej surrealistyczny sposób. Tam, gdzie na początku zarysowywał się sens i potencjalne wytłumaczenie akcji, stopniowo wkrada się nihilistyczny absurd.

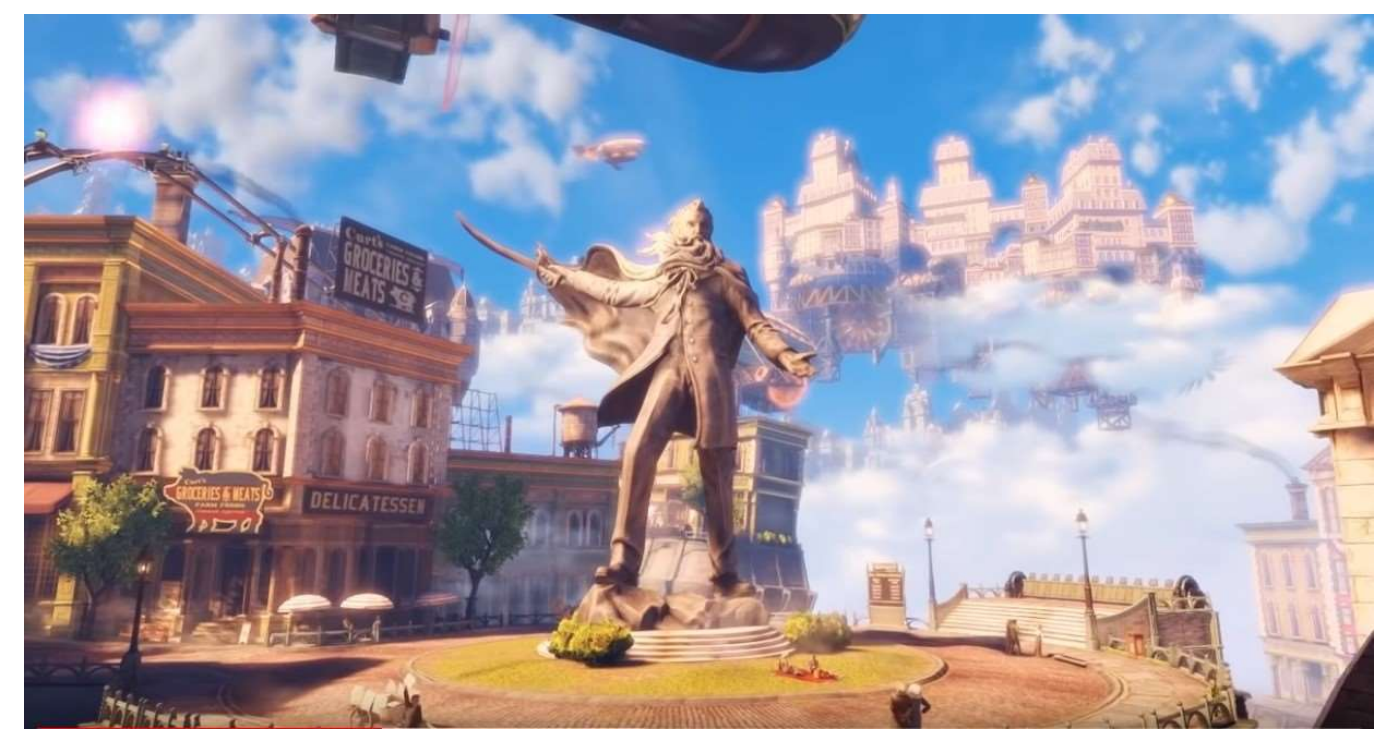

Columbia, Bioshock: Infinite

Najlepszym odwzorowaniem "miasta dziennego" jest idealne miasto (citta ideale) renesansowych utopistów. Opisywane w utopiach Thomasa More'a, Francisa Bacona czy Tomasso Campanelli struktury miast-państw odzwierciedlają ideał wychowawczy superego. Jak twierdzi Heinz Paetzold: 
„Koncepcja miasta jako naturalnego otoczenia, w którym człowiekowi dane jest osiągnąć pełnię człowieczeństwa, byłby zatem tegoż miasta utopią"30. Z punktu widzenia psychoanalizy, wizja doskonale zorganizowanego miasta jest jedynie projekcją ideału superego. Wbrew przytoczonym słowom i tym bardziej wbrew intencjom twórców utopijnych miast - czy w postaci literackiej, czy, już w XIX i $\mathrm{XX}$ wieku, w postaci realizacji architektonicznych - miasto idealne przeistacza się $\mathrm{w}$ swoje przeciwieństwo, czyli $\mathrm{w}$ dystopię ${ }^{31}$. Ich pojawienie się to „powrót wypartego" będący dla Freuda źródłem nerwicy ${ }^{32}$. Utopie renesansowe odzwierciedlają zachodni model racjonalności, który został poddany krytyce przez psychoanalizę.

Gdy w 1912 roku, jako Booker DeWitt, skompromitowany detektyw z kliszy kina noir, przyjmujemy zlecenie odnalezienia zaginionej młodej kobiety, rozpoczyna się nasza podróż do miejsca zgoła niezwykłego, Columbii unoszącego się za pomocą balonów i parowej maszynerii latającego miasta, które, stworzone w ramach Wystawy Światowej, by symbolizować amerykańskiego ducha, od prawie dekady pozostaje w całkowitej izolacji. Tak zarysowuje się początek fabuły gry Bioshock: Infinite, szybko rzucając gracza w wir narracji. Gdy docieramy na miejsce, ukazuje nam się niebiański, wręcz groteskowy widok i słyszymy śpiew kościelnego chóru. Rządzący miastem wielebny Comstock opiewany jest jako prorok, a beztroska atmosfera miasta przypomina wieczny festyn. Bardzo szybko jednak spod idyllicznych oparów zaczyna wyzierać zgnilizna: niewolnictwo, ksenofobia, rasizm, eugenika i brutalny totalitaryzm skrywany przez teokrację. Chociaż miasto to kreuje się na chrześcijańskie Niebo, w rzeczywistości zbudowane jest na najniższych ludzkich pobudkach i ziemskiej niegodziwości maskowanej wszechobecną egzaltacją wzniosłych i sielankowych fasad.

${ }^{30}$ Heinz Paetzold, „Polityka przechadzki”, tłum Ewa Mikina, w: Formy estetyzacji przestrzeni publicznej, red. Jan S. Wojciechowski, Anna Zeidler-Janiszewska (Warszawa: Instytut Kultury, 1998), 118.

${ }^{31}$ Zob. Ewa Rewers, Post-polis. Wstęp do filozofii ponowoczenesgo miasta (Kraków: Universitas, 2005), 256.

32Zob. Rosińska, Freud (Warszawa: Wiedza Powszechna, 1993), 50-51. 


\section{Podsumowanie}

W swych przedstawieniach, miasto jest przestrzenią wyobrażoną, manifestacją popędów i braków. Jest projektem fantazmatycznym, czyli sposobem mitologizowania przestrzeni, w której żyjemy na co dzień. Przestrzeń miejska jest więc zarówno obszarem projekcji cienia naszej cywilizacji, jak i próbą łagodzenia rosnących stąd lęków - poprzez odnajdywanie schematów mitycznych, archetypowych, które od zawsze niosły pocieszenie ludzkości. Symbolika miasta charakteryzuje się więc ambiwalencją, sięgająca samych jego początków. Dobrze ją opisuje W. Toporow: „I świadomości wczorajszych hodowców bydła i rolników oferuje się dwa obrazy miasta, dwa bieguny możliwego rozwoju tej idei - miasto przeklęte, upadłe i rozpustne, miasto nad otchłanią i miasto-otchłań, oczekujące kar niebieskich, oraz miasto przemienione i okryte sławą, nowy gród, zesłany z nieba na ziemię"33. Miasto jawi się jako swoista coincidentia oppositorum - jedność przeciwieństw, w której odbija się jak w krzywym zwierciadle spolaryzowana ludzka psyche. Ze względu na to pozostaje bogatym punktem odniesień i atrakcyjnym narzędziem fabularnym. Można więc przyjąć, że miasto nie jest nie tylko pomnikiem ludzkiego rozwoju kulturalnego i cywilizacyjnego, lecz także aktywnym artefaktem, który kulturę tę podtrzymuje i reprodukuje, pozostając w ciągłej dialektyce z ludzką nieświadomością, która w rewanżu nieustannie nakłada na miasto swoje projekcje. Dlatego hermeneutyczna interpretacja jego przedstawień nie traci na aktualności, niezależenie od stopnia zaawansowania czy rodzaju mediów, $\mathrm{w}$ których przedstawienia te są realizowane.

\section{Bibliografia}

Adams, Ernest, Joris Dormans. Game Mechanics: Advanced Game Design. Berkley: New Riders, 2012.

Cambell, Joseph. Bohater o tysiącu twarzy. Tłum. Andrzej Jankowski. Kraków: NOMOS, 2013.

Czemiel, Grzegorz. „Psychoanaliza polis. Przyczynek do badań nad przestrzennymi praktykami politycznymi”. Śląskie Studia Polonistyczne 1, nr 3 (2013): 129-43.

Eliade, Mircea. Historia wierzeń $i$ idei religijnych, t. 1. Tłum. Stanisław Tokarski. Warszawa: Instytut Wydawniczy PAX, 1988.

${ }^{33}$ Wladimir Toporow, Miasto i mit, tłum. Bogusław Żyłko (Gdańsk: Słowo/Obraz Terytoria, 2000), 34 . 
Eliade, Mircea. Historia wierzeń i idei religijnych, t. 2. Tłum. Stanisław Tokarski. Warszawa: Instytut Wydawniczy PAX, 1994.

Eliade, Mircea. Mit wiecznego powrotu. Tłum. Krzysztof Kocjan. Warszawa: Wydawnictwo KR, 1988.

Freud, Zygmunt. Poza zasadą przyjemności. Tłum. Jerzy Prokopiuk. Warszawa: PWN, 1975.

Freud, Zygmunt. Wykłady ze wstepu do psychoanalizy. Nowy cykl. Tłum. Robert Reszke. Warszawa: Wydawnictwo KR, 2009.

Fromm, Erich. Miłość, płeć i matriarchat. Tłum. Beata Radomska, Grzegorz Sowiński. Poznań: REBIS, 2011.

Garda, Maria B. Interaktywne fantasy. Gatunek $w$ grach cyfrowych. Łódź: Wydawnictwo Uniwersytetu Łódzkiego, 2016.

Graham, Wade. Miasta wyśnione. Siedem wizji urbanistycznych, które kształtują świat. Tłum. Anna Sak. Kraków: Wydawnictwo Karakter, 2016.

Hayot Eric, Wesp Edward. „Towards a Critical Aesthetic of Virtual-World Geographies”. The International Journal of Computer Game Research 9, $\mathrm{nr} 1$ (2009), http://gamestudies.org/0901/articles/hayot_wesp_space Dostęp 11.12.2017

Jacobi, Jolande. Psychologia C.G. Junga. Wprowadzenie do całości dzieła. Tłum. Stanisław Łypacewicz. Warszawa: Wydawnictwo Wodnika, 1993.

Jung, Carl Gustav. Civilization in Transition. London: Routledge \& Kegan Paul, 1964.

Jung, Carl Gustav. Psychologia a alchemia. Tłum. Robert Reszke. Warszawa: Wydawnictwo KR, 1999.

Jung, Carl Gustav. Psychologia a religia Zachodu i Wschodu. Tłum. Robert Reszke. Warszawa: Wydawnictwo KR, 2005.

Kohler, Chris. Power Up: How Japanese Video Games Gave the World an Extra Life. New York: Dover Publications, 2016.

Kutter, Peter. Współczesna psychoanaliza. Tłum. Aleksandra Ubertowska. Gdańsk: Gdańskie Wydawnictwo Psychologiczne, 1998.

Mitchell, Stephen, Margaret Black. Freud i inni. Historia myśli psychoanalitycznej. Tłum. Joanna Gilewicz. Kraków: Wydawnictwo Uniwersytetu Jagiellońskiego, 2017.

Neumann, Erich. Wielka matka. Fenomenologia kobiecości. Kształtowanie nieświadomości. Tłum. Robert Reszke. Warszawa: Wydawnictwo KR, 2008.

Paetzold, Heinz. „Polityka Przechadzki”. Tłum. Ewa Mikina. W: Formy estetyzacji przestrzeni publicznej, red. Jan Wojciechowski, Anna Zeidler-Janiszewska, 117-129. Warszawa: Instytut Kultury, 1998.

Petry, Arlete dos Santos, Luís Carlos Petry. „Possibilities of Encounter between Psychoanalysis and Videogames: Thinking with Freud and Lacan”. W: XI Simpósio Brasileiro de Jogos e Entretenimento Digital - SBGames 2012 (2012): 9-18.

Rewers, Ewa. Post-polis. Wstęp do filozofii ponowoczenesgo miasta. Kraków: Universitas, 2005. Rosińska, Zofia. Freud. Warszawa: Wiedza Powszechna, 1995.

Rosińska, Zofia. Psychoanalityczne myślenie o sztuce. Warszawa: PWN, 1985. 
Sapkowski, Andrzej. Rękopis znaleziony w smoczej jamie. Kompendium wiedzy o literaturze fantasy. Warszawa: Supernowa, 2001.

Szmidt, Bolesław. Lad Przestrzeni. Warszawa: Państwowy Instytut Wydawniczy, 1981.

Szyjewski, Andrzej. Etnologia Religii. Kraków: NOMOS, 2001.

The Video Game Explosion: A History from PONG to Playstation and Beyond, red. Mark J.P. Wolf. Westport, Connecticut, London: Greenwood Press, 2008.

Toporow, Władimir. Miasto i mit. Tłum. Bogusław Żyłko. Gdańsk: Słowo/Obraz Terytoria, 2000.

Tucci, Giuseppe. Mandala. Tłum. Ireneusz Kania. Kraków: Znak, 2002.

Wolf, Mark J.P. Building Imaginary Worlds: The Theory and History of Subcreation. New York and London: Rouledge, 2012.

\section{Ludografia:}

Alan Wake, Remedy Entertainment, Microsoft Game Studios, 2012.

BioShock Inifinite, Irrational Games, Cenega S.A., 2013.

Dragon Quest, Chunsoft, Nintendo, 1989.

Elex, Pirhania Bytes, CD Projekt, 2017.

Hotline Miami, Dennaton Games, Devolver Digital, 2012.

The Elder Scrolls III: Morrowind, Bethesda Game Studios, CD Projekt, 2002.

Torment: Tides of Numenera, inXile Entertainment, Techland, 2017.

War of Warcraft, Blizzard Entertainment, CD Projekt, 2005.

Wolfenstein: The New Order, Machine Games, Cenega S.A., 2014.

\section{Summary}

\section{City, Myth, and Psyche in the Imaginary of Video Games. Symbolism of Cities and City Performances - Psychoanalytical Approach.}

The article attempts to present the symbolism of the city on the basis of psychoanalysis as the hermeneutics of culture. Combining mythical motifs with examples of various portrayals of the cityscape in video games, it outlines the inseparable ambivalence of the urban symbolism, following the Freudian personality structure and an expression of complexes that make up the constitution of the human psyche. The use of video games affirms the versatility of the psychoanalytical hermeneutics program and accommodates the so-called New Media to the scope of research interests in psychoanalysis. 
Keywords: psychoanalysis, hermeneutics, city, video games, mythology

$$
\text { Zusammenfassung }
$$

\section{Die Stadt, der Mythos und die Psyche. Die Symbolik der Städte und der Stadtvorstellungen im Imaginarium der Videospiele - ein psychoanalytischer Ansatz}

Der Artikel unternimmt den Versuch, die Symbolik der Stadt auf dem Boden der Psychoanalyse als Hermeneutik der Kultur darzustellen. Das Nebeneinanderstellen von mythischen Motiven mit den Beispielen von Stadtvorstellungen in Videospielen lässt eine untrennbare Ambivalenz des Stadtmotivs skizzieren, die der Freudschen Persönlichkeitsstruktur folgt und ein Ausdruck von Komplexen ist, die die menschliche Psyche konstituieren. Der Gebrauch von Videospielen bejaht die Universalität des Programms der psychoanalytischen Hermeneutik und bezieht ebenfalls sog. Neue Medien in den Bereich des Forschungsinteresses der Psychoanalyse.

Schlüsselworte: Psychoanalyse, Hermeneutik, Stadt, Videospiele, Mythologie

Information about Author:

MIROSŁAW PIRÓG, habilitated doctor, Institute of Philosophy, Faculty of Humanities, University of Silesia; address for correspondence: ul. Bankowa 11, 40-007 Katowice; e-mail: miroslaw.pirog@us.edu.pl

LINDA BEREZOWSKA, BA in philosophy (UŚ); address for correspondence: ul. Bankowa 11, 40-007 Katowice; e-mail: linda.berezowska@gmail.com 